\title{
A NEW GREEN CATALYST FOR SYNTHESIS OF BIS-MACROMONOMERS OF POLYETHYLENE GLYCOL (PEG)
}

\author{
Sara Haoue $^{1}$, Hodhaifa Derdar $^{1,2,} \otimes$, Mohammed Belbachir ${ }^{1}$, Amine Harrane $^{1,3}$
}

https://doi.org/10.23939/chcht14.04.468

\begin{abstract}
A new method to synthesise polyethylene glycol dimethacrylate (PEGDM) with various molecular weights $(1000,3000,6000$ and $8000 \mathrm{~g} / \mathrm{mol})$ of polyethylene glycol (PEG) has been developed. This technique consists in using Maghnite- $\mathrm{H}^{+}$as eco-catalyst to replace eriethylamine, which is toxic. Maghnite- $\mathrm{H}^{+}$is a proton exchanged montmorillonite clay which is prepared through a simple exchange process. Synthesis experiments are performed in solution using dichloromethane as solvent in the presence of methacrylic anhydride. The effect of reaction time, temperature, amount of catalyst and amount of methacrylic anhydride is studied in order to find the optimal reaction conditions. The synthesis in solution leads to the best yield ( $98 \%$ ) at room temperature for the reaction time of $5 \mathrm{~h}$. The structure of the obtained macromonomers (PEGDM) is confirmed by FTIR, ${ }^{1} \mathrm{H} N M R$ and ${ }^{13} \mathrm{C}$ NMR, where the methacrylate end groups are clearly visible. Thermogravimetric analysis (TGA) is used to study the thermal stability of these obtained macromonomers. The presence of unsaturated end group was confirmed by UV-Visible analysis.
\end{abstract}

Keywords: PEGDM, one-pot synthesis, Maghnite-H+, macromonomers, methacrylic anhydride.

\section{Introduction}

Producing polymers based on renewable monomers has been the subject of several current research groups around the world. Among different types of polymers explored, polymers based on renewable resources have been studied most extensively [1]. Polyethylene glycol (PEG) is a non-toxic polymer with many applications in the

\footnotetext{
${ }^{1}$ Oran1 University Ahmed Benbella BP Nº 1524 El M’Naouar, 31000 Oran, Algeria

${ }^{2}$ Centre de Recherche Scientifique et Technique en Analyses PhysicoChimiques (CRAPC), BP 10 384, Siège ex-Pasna Zone Industrielle, Bou-Ismail CP 42004, Tipaza, Algeria

${ }^{3}$ Department of Chemistry, FSEI University of Abdelhamid Ibn Badis Mostaganem, Algeria

hodhaifa-27@outlook.fr

(c) Haoue S., Derdar H., Belbachir M., Harrane A., 2020
}

industrial, medical and biological fields. The first study and characterization of PEG was conducted in 1860 by Laurenço [2]. PEG is the basis of various laxatives and also is used as excipient in pharmaceutical products and as a cancer drug delivery in targeted diagnostics [3]. When joined to different protein prescriptions, PEG also permits a slow clearance of the carried protein in the blood and is used in many commercial products [4].

Various polyethylene glycol (PEG) macromonomers have been reported in the scientific literature for many years. These PEG macromonomers were prepared from block copolymers between PEG and biodegradable polyesters [5] or by acrylation and methacrylation of PEG [6-9]. One of the main advantages of using PEG macromonomers is the preparation of biomaterials hydrogel. Over the past years, polyethylene glycol dimethacrylate (PEGDM) is synthesized by reacting PEG with methacryloyl chloride and triethylamine in the solution using dichloromethane as a solvent, at room temperature overnight [10] and for $24 \mathrm{~h}$ [11], with another methods extending reaction time to 4 days [12] before filtration and precipitation in diethyl ether. However, all these approaches are time-consuming and not environmentally friendly, as they involve the use of relatively large amounts of toxic reagents and solvents.

Generally, almost all the catalysts used for the preparation of polymers present great environmental problems, as they are corrosive. The main drawbacks of the application of zinc and silver compounds, as well as Lewis acids, are their difficulty to be handled and separated, which means they are often destroyed in this process. Moreover, zinc or silver compounds require environmental reconditioning [13].

To circumvent these limitations, in this paper we use a new method to synthesise PEGDMs with different molecular weight of PEG $(1000,3000,6000$, and $8000 \mathrm{~g} / \mathrm{mol}$ ) using an Algerian montmorillonite clay called Maghnite- $\mathrm{H}^{+}$as a catalyst. In our previously published work we have shown the advantage of different applications of this catalyst type in several polymerization reactions [14]. It is preferred for its many advantages such as very low purchase price compared to other catalysts 
and the easy of removal of the reaction mixture, regenerated by heating to the temperature above $373 \mathrm{~K}$ [15]. In this work, a very detailed study on the catalytic properties of Algerian clay $\left(\mathrm{Mag}-\mathrm{H}^{+}\right)$is developed. FTIR, ${ }^{1} \mathrm{H} N M R,{ }^{13} \mathrm{C}$ NMR, TGA and UV-Vis analysis show that the (PEGDM) macromonomers were successfully obtained.

\section{Experimental}

PEG with different molecular weight $\left(M_{n}=1000\right.$, 3000, 6000, and $8000 \mathrm{~g} / \mathrm{mol}$ ), methacrylic anhydride (94\%), diethyl ether (99.7\%) and dichloromethane (99.8\%) were purchased from Sigma Aldrich and used as received. The raw montmorillonite clay was obtained from ENOF Maghnia (Algerian manufacture specialized in the production of non-ferric products and useful substances).

\subsection{Characterization}

The X-ray powder diffraction profiles for pressed powder samples were recorded on a D8 Discover Bruker diffractometer using $\mathrm{Cu}-\mathrm{K} \alpha$ radiation $(\lambda=1.5418 \AA)$. FTIR absorption spectra were recorded on an Alpha Bruker FTIR spectrometer. NMR is a very powerful analytical method for the elucidation of chemical structures. ${ }^{1} \mathrm{H}$ NMR and ${ }^{13} \mathrm{C}$ NMR spectra were recorded on a Brucker-Avance $400 \mathrm{MHZ}$ apparatus in a deuterated chloroform. Polymer thermal stability was assessed using thermogravimetric analysis (TGA) using PerkinElmer STA 6000 under nitrogen in the temperature range of $303-973 \mathrm{~K}$ with the heating rate of $20 \mathrm{~K} / \mathrm{min}$ and the sample weight of about $6 \mathrm{mg}$. UV-Vis diffuse reflectance spectra were recorded using a SPECORD 210 Analytik Jena spectrometer. DSC measurements were carried out on Netzsch DSC 204 F1 Phonix 240-12-010-L, according to the following program: the specimens were heated at the rate of $10 \mathrm{~K} / \mathrm{min}$ from 223 to $283 \mathrm{~K}$.

\subsection{Preparation of Maghnite $-\mathbf{H}^{+}$}

Maghnite- $\mathrm{H}^{+}$is prepared according to the process reported in our previous study [16-20]. Maghnite- $\mathrm{H}^{+}$is activated with a sulfuric acid solution to give a Maghnite exchanged with protons, called $\mathrm{Mag}-\mathrm{H}^{+}$. In an Erlenmeyer flask, crushed raw Maghnite $(20 \mathrm{~g})$ is dispersed in a volume of distilled water $(120 \mathrm{ml})$. The mixture is stirred for $2 \mathrm{~h}$ at room temperature. Then, a solution of sulfuric acid $(0.25 \mathrm{M})$ is added. The solution thus obtained is maintained for two days under stirring. The mineral is filtered off and washed several times with distilled water up to $\mathrm{pH} 7$. After filtration, $\mathrm{Mag}-\mathrm{H}^{+}$is dried in an oven for $24 \mathrm{~h}$ at $378 \mathrm{~K}$ and then crushed. Its structure is established by FTIR and XRD.

\subsection{Synthesis of PEGDM Macromonomers}

The synthesis of PEGDM (Scheme 1) was carried out in solution using dichloromethane as solvent. In a flask containing $2 \mathrm{~g}$ of PEG $(1000 \mathrm{~g} / \mathrm{mol})$, we added $10 \mathrm{wt} \% \mathrm{t}$ of $\mathrm{Mag}-\mathrm{H}^{+}$, which was previously dried for $30 \mathrm{~min}$ in the oven at $378 \mathrm{~K}$. The mixture was stirred for $1 \mathrm{~h}$ at room temperature $(298 \mathrm{~K})$, and then we added $10 \mathrm{wt} \%$ of methacrylic anhydride under stirring for $4 \mathrm{~h}$. Then, the same experimental protocol was performed varying the molecular weight of PEG (3000, 6000 and $8000 \mathrm{~g} / \mathrm{mol}$ ). The catalyst was removed from the mixture by simple filtration. The filtrate was precipitated in cold diethyl ether. The precipitated product was filtered and dried under vacuum over night, weighed and analyzed by ${ }^{1} \mathrm{H}$ NMR, ${ }^{13} \mathrm{C}$ NMR, FTIR and DSC.

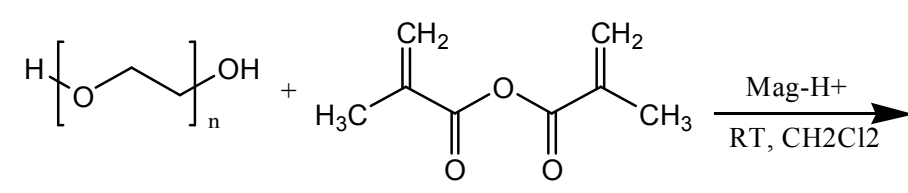

PEG

Methacrylic Anhydride<smiles>C=C(C)C(=O)OCCOC(C)C(=O)C(=C)C</smiles>

PEGDM

Scheme 1. Synthesis of PEGDM macromonomers

\section{Results and Discussion}

\subsection{Characterization of Maghnite- $\mathrm{H}^{+}$}

X-ray diffractograms of Raw-Mag and $\mathrm{Mag}-\mathrm{H}^{+}$are shown in Fig. 1. The calculated basal spacing $\left(\mathrm{d}_{001}\right)$ from XRD patterns, applying Bragg equation $(2 d \sin \theta=n \lambda)$ is $12.5 \AA$ for Raw-Mag and $14.5 \AA$ for Mag- $\mathrm{H}^{+}$. This increase in basal spacing is explained by the substitution of single water between the sheet of Raw-Mag by two interlamellar water layer in Mag- $\mathrm{H}^{+}[21]$.

FTIR spectrum of Maghnite- $\mathrm{H}^{+}$(Fig. 2) is recorded in order to check the quality of the catalyst preparation. The hydrated structure of Maghnite- $\mathrm{H}^{+}$results in characteristic vibrations of hydroxyl groups around 3400 and $3600 \mathrm{~cm}^{-1}$. Various $\mathrm{Si}-\mathrm{O}$ vibrations mode at 1007 , 
756, 518, and $449 \mathrm{~cm}^{-1}$ can be attributed to the montmorillonite clay structure. All these expected absorption bands confirm that the structure of the compound is thus in good agreement with vibration values obtained from the literature [22].

\subsection{Characterization of PEGDM Macromonomers}

\subsubsection{NMR measurements} $\left({ }^{1} \mathrm{H}\right.$ NMR and ${ }^{13} \mathrm{C}$ NMR)

${ }^{1} \mathrm{H}$ NMR spectra of macromonomers was recorded in $\mathrm{CDCl}_{3}$. The ${ }^{1} \mathrm{H}$ NMR spectrum allowed us to confirm the structure of the obtained product. The methacrylate

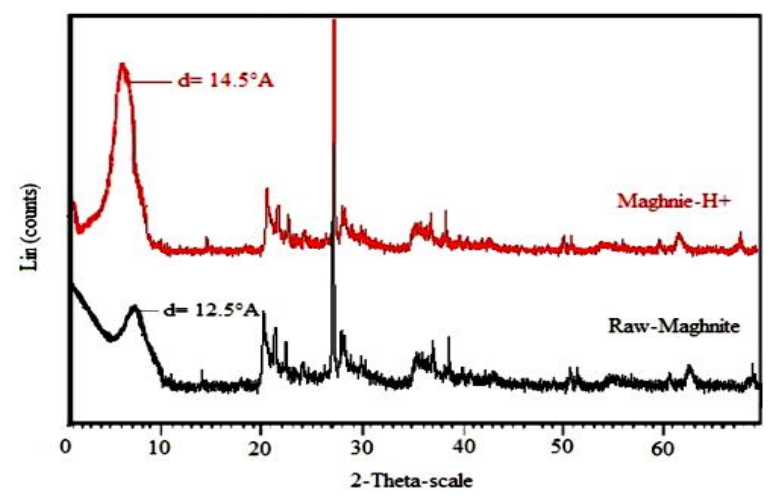

Fig. 1. X-Ray diffractogram of Raw-Mag and Mag- $\mathrm{H}^{+}(0.25 \mathrm{M})$

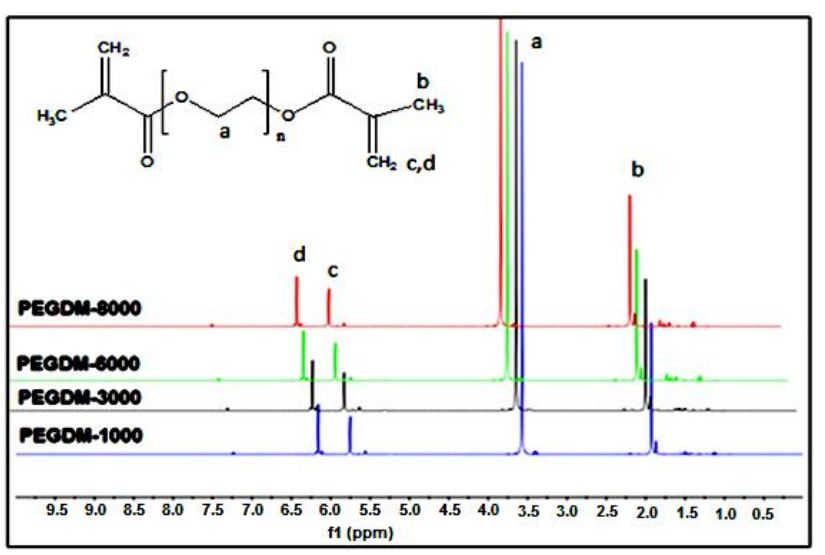

Fig. 3. ${ }^{1} \mathrm{H}$ NMR spectrum of the obtained PEGDM macromonomers

\subsubsection{FTIR measurements}

FTIR spectra of PEG and PEGDM are shown in Fig. 5. The FTIR spectrum of PEGDM (B) shows intense band at $1715 \mathrm{~cm}^{-1}$ corresponding to the valence vibration of the $\mathrm{C}=\mathrm{O}$ of ester group. Methacrylate group is linked to end groups were clearly visible in the ${ }^{1} \mathrm{H}$ NMR spectrum of macromonomer product, as shown in Fig. 3. The protons of $=\mathrm{CH}_{2}$ end group assigned a signal at 5.8 and $6.1 \mathrm{ppm}$. The signal at $3.6 \mathrm{ppm}$ is attributed to the PEG protons and the signal observed at $1.9 \mathrm{pm}$ is attributed to the methyl protons $\left(\mathrm{CH}_{3}\right)$ of methacrylic anhydride.

The ${ }^{13} \mathrm{C}$ NMR spectrum of macromonomers is shown in Fig. 4, the signal at $70.1 \mathrm{ppm}$ is attributed to the PEG carbons, and ester function assigned a signal at $163 \mathrm{ppm}$. The $\mathrm{CH}_{3}$ group of methacrylic anhydride is assigned as a signal at $17.7 \mathrm{ppm}$. The vinyl carbons of methacrylic anhydride are assigned as a signal at 128 and $135 \mathrm{ppm}$, which clearly shows that the synthesis of PEGDM macromonomers is successful with Mag- $\mathrm{H}^{+}$.

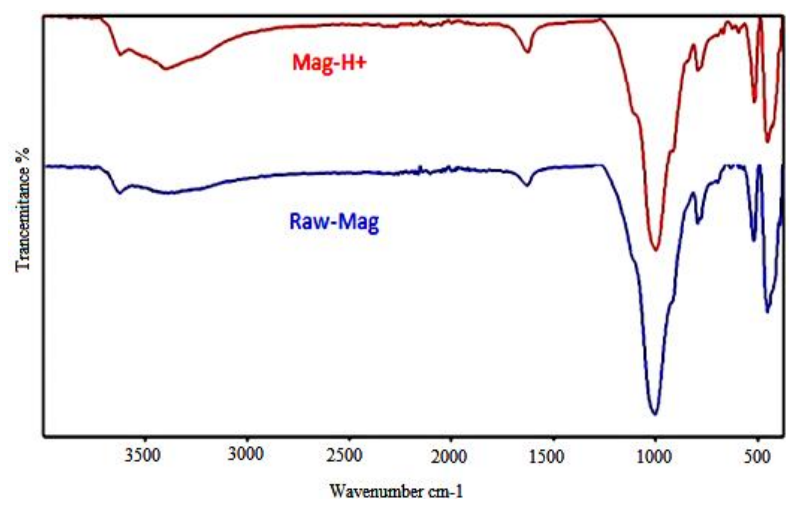

Fig. 2. FTIR spectrum of Raw-Mag and Mag- $\mathrm{H}^{+}$

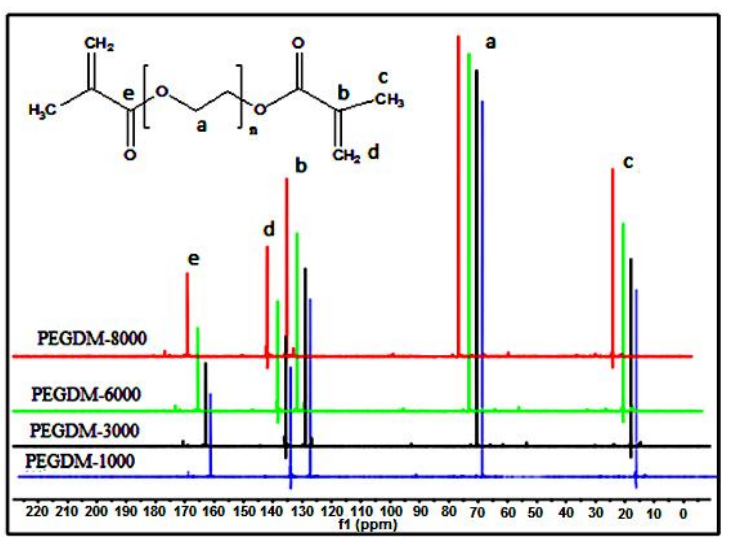

Fig. 4. ${ }^{13} \mathrm{C}$ NMR spectrum of the obtained PEGDM macromonomers

the end of PEG polymer chain by an ester function CO. A less intense band at $1636 \mathrm{~cm}^{-1}$ corresponds to the valence vibration of the $\mathrm{C}=\mathrm{C}$ bond, compared to the spectrum of PEG in which those bands are nonexistent. The band at $2855 \mathrm{~cm}^{-1}$ corresponds to the $\mathrm{C}-\mathrm{H}$ of the polymer. It should be noted that the characteristic band corresponding 
to the band of $\mathrm{OH}$ groups at $3500 \mathrm{~cm}^{-1}$ in the spectrum of PEG (A) have disappeared in the spectrum of PEGDM (B). This fact confirms that the synthesis of PEGDM macromonomers is successful with Mag- $\mathrm{H}^{+}$.

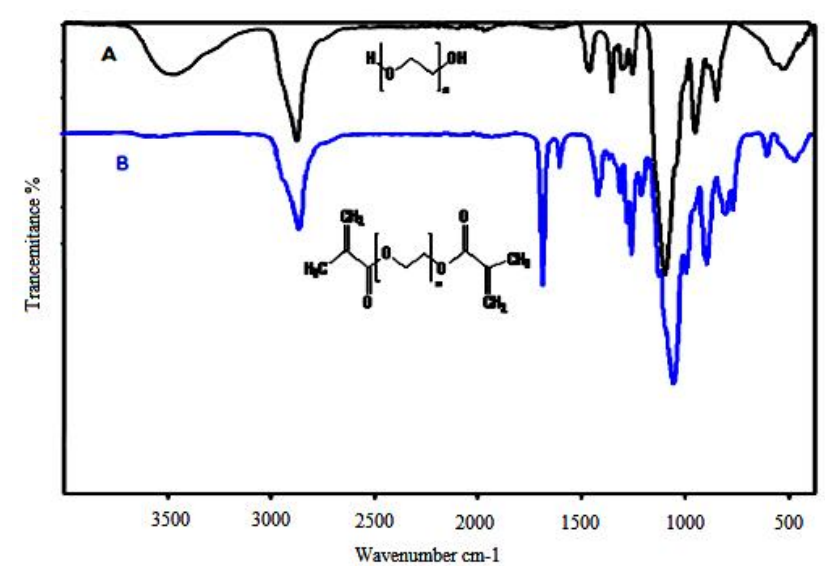

Fig. 5. FTIR spectra of PEG (A) and PEGDM macromonomer (B)

\subsubsection{UV-Visible analysis (UV-Vis)}

UV-Vis analysis allows assaying the unsaturated end group. The dichloromethane was taken as a solvent, and $0.1 \mathrm{~g}$ of each sample was diluted in $50 \mathrm{ml}$ of dichloromethane and then its absorbance was measured. The double bond was observed at $\lambda=241.5 \mathrm{~nm}$ (Fig. 6). UV-Vis analysis confirms the results of FTIR and NMR analyses.

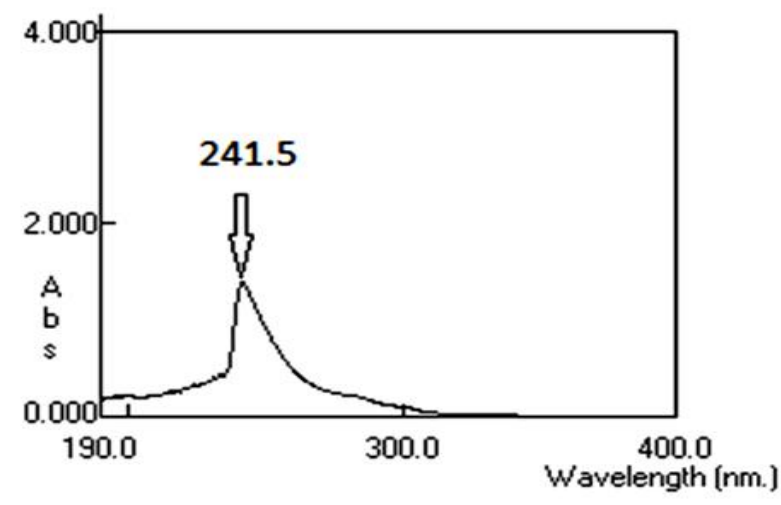

Fig. 6. UV-Vis spectrum of the obtained PEGDM macromonomers

\subsubsection{Thermogravimetric analysis (TGA)}

Thermal stability of the obtained PEGDM macromonomer $(6000 \mathrm{~g} / \mathrm{mol})$ and PEG $(6000 \mathrm{~g} / \mathrm{mol})$ is shown in Fig. 7. The figure shows that the end capping with methacrylic anhydride is effective since degradation occurred at higher temperatures. This result confirms the previous ${ }^{1} \mathrm{H} N \mathrm{NM}$ results. In the temperature range of $523-593 \mathrm{~K}$ the weight loss was found to be $91.17 \%$, that can be reasonably attributed to the weight loss of the polymer and to the decomposition of PEGDM chains.

\subsubsection{Differential scanning calorimetry (DSC)}

The thermal properties of the obtained macromonomer PEGDM $(6000 \mathrm{~g} / \mathrm{mol})$ are determined by DSC. Fig. 8 shows the results of the DSC measurements. The glass transition temperature $\left(T_{g}\right)$ of the PEGDM is observed in the temperature range of 243-233 K, the same result was obtained by Simon et al. [23].

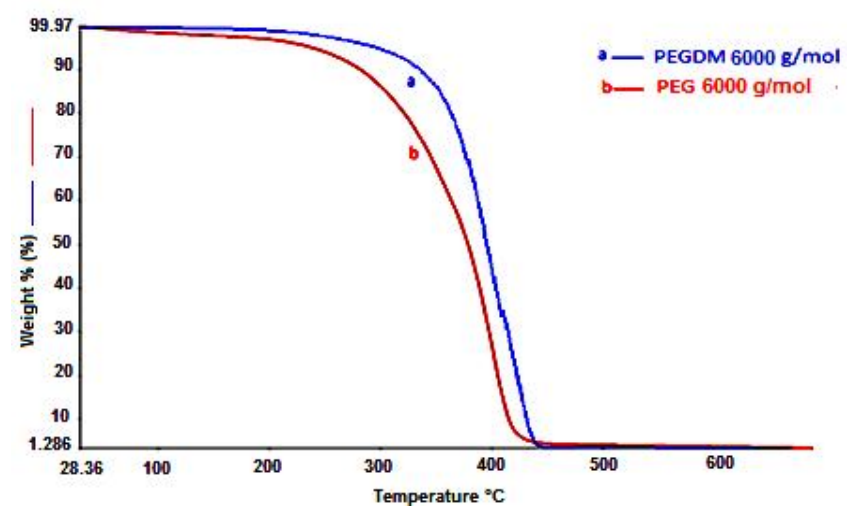

Fig. 7. TGA thermograms of the obtained macromonomers

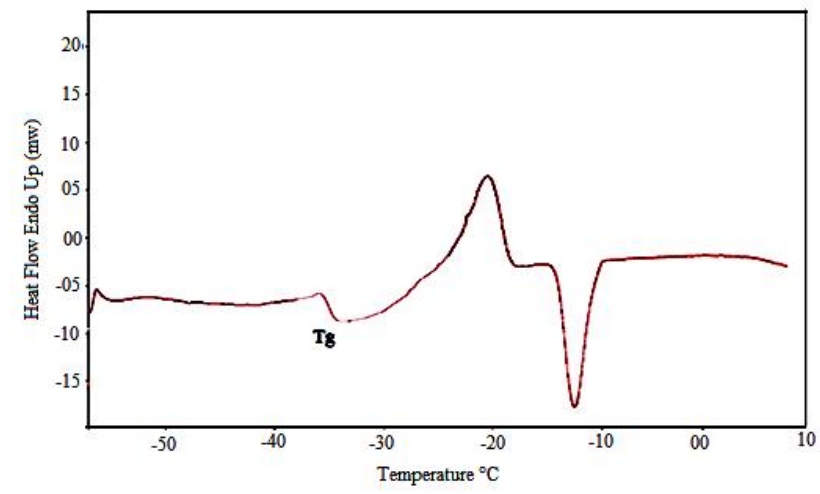

Fig. 8. DSC thermogram of the obtained macromonomer PEGDM (6000 g/mol)

\subsection{Determination of Optimal Reaction Conditions}

The objective of this part is to study the effect of various parameters including the quantity of the catalyst, quantity of methacrylic anhydride and the reaction time on the yield of the obtained macromonomers in order to find the optimum conditions for the reaction. The yield (\%) was calculated by Eq. (1): 


$$
\text { Yield }=\frac{M_{0}}{M_{1}} \cdot 100
$$

where $M_{0}$ and $M_{1}$ are weights of the obtained macromonomer (PEGDM) and the initial polymer (PEG), respectively.

\subsubsection{Effect of Mag- $\mathrm{H}^{+}$amount on the PEGDM yield}

Fig. 9 shows the effect of the catalyst amount on the yield of the obtained macromonomers (PEGDM). The synthesis was carried out at $298 \mathrm{~K}$ for $5 \mathrm{~h}$ using various amounts of Mag- $\mathrm{H}^{+}(2,5,7,10$, and $12 \mathrm{wt} \%)$. The reaction was carried out in solution with $10 \mathrm{wt} \%$ of methacrylic anhydride. One can see from the figure that the yield of macromonomers increased with the amount of Mag- $\mathrm{H}^{+}$. The yield increases according to the quantity of Mag- $\mathrm{H}^{+}$up to the optimal point, which corresponds to $10 \mathrm{wt} \%$. This behavior is explained by the increase of active sites available in $\mathrm{Mag}-\mathrm{H}^{+}$responsible for the initiation and acceleration of the reaction until the saturation of these sites. Similar results were obtained by Belbachir and coworkers [24].

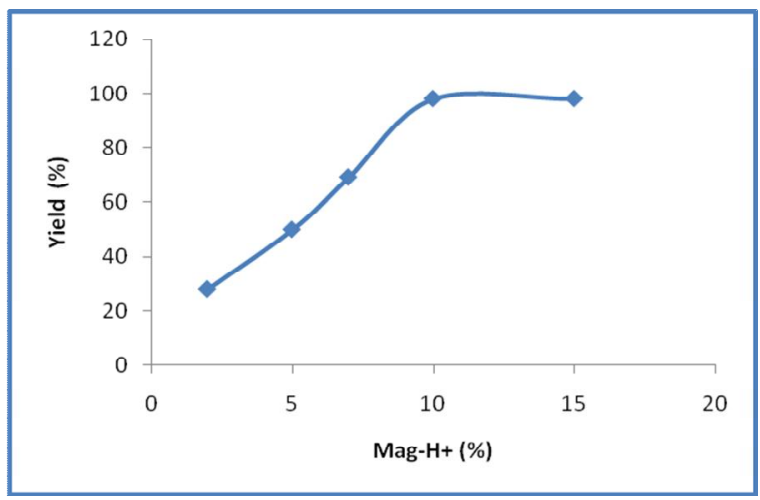

Fig. 9. Effect of the Mag- $\mathrm{H}^{+}$amount on the PEGDM yield

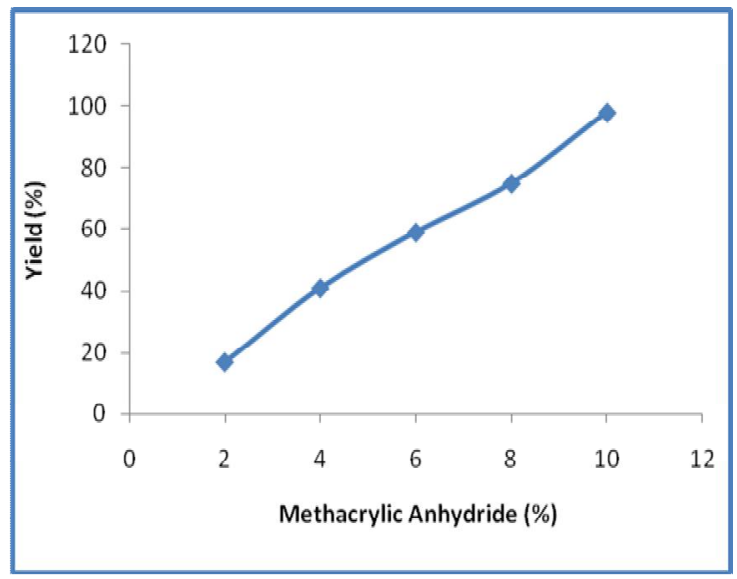

\subsubsection{Effect of time on the PEGDM yield}

Fig. 10 shows the yield of the macromonomers versus time for the PEGDM synthesis using Mag- $\mathrm{H}^{+}$ as the catalyst. At $298 \mathrm{~K}$ after $5 \mathrm{~h}$ the reaction takes place quickly, reaching the best yields $(98 \%)$ in the presence of $10 \mathrm{wt} \%$ of $\mathrm{Mag}-\mathrm{H}^{+}$. After this time, the reaction slows down gradually, and the yield becomes almost constant. This behavior is explained by the nature of the reaction proceeded in the solution.

\subsubsection{Effect of methacrylic anhydride on the PEGDM yield}

Different contents of methacrylic anhydride were used to produce PEGDM. The effect of these contents on the methacrylation reaction was studied. Selective results are shown in Fig. 11. As could be seen, when the concentration of methacrylic anhydride is increased, the yield of the obtained macromonomer increases. The synthesis with $10 \mathrm{wt} \%$ of methacrylic anhydride gave the highest yield (up to $98 \%$ ).

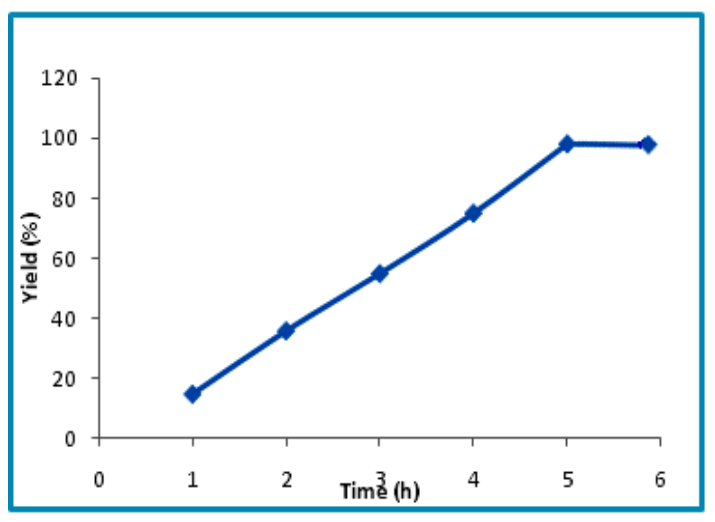

Fig. 10. Effect of the reaction time on the PEGDM yield

Fig. 11. Effect of the methacrylic anhydride amount on the PEGDM yield 


\section{Conclusions}

In the present work we have developed a new method to synthesize PEGDM macromonomers. These materials were prepared using an Algerian clay $\left(\right.$ Maghnite- $\left.\mathrm{H}^{+}\right)$that could be used as green and ecocatalyst. The synthesis of PEGDM macromonomers over Maghnite- $\mathrm{H}^{+}$provides excellent results, in the presence of methacrylic anhydride, at room temperature and in one step. The influencing factors on the synthesis reaction were studied, and the optimal reaction conditions were obtained: the yield achieved its maximum (98\%) with $10 \mathrm{wt} \%$ of the catalyst and $10 \mathrm{wt} \%$ of methacrylic anhydride at room temperature for $5 \mathrm{~h}$, according to the increase in acidic active centers. The resulting products were perfectly characterized by FTIR, ${ }^{1} \mathrm{H}$ NMR, ${ }^{13} \mathrm{C}$ NMR, TGA, and UV-Vis analyses. Maghnite- $\mathrm{H}^{+}$is an efficient, cheap and environmentally friendly catalyst. Its use for the synthesis of PEGDMs macromonomers leads to good results.

\section{References}

[1] Vilela C., Sousa A, Fonseca A. et al.: Polym. Chem., 2014, 5, 3119. https://doi.org/10.1039/c3py01213a

[2] Kricheldorf H.: Experiments Before World War I. [in:] Polycondensation. Springer, Berlin, Heidelberg 2014, 7-25. https://doi.org/10.1007/978-3-642-39429-4 2

[3] Hutanu D., Frishberg M., Guo L., Darie C.: Mod. Chem. Appl., 2014, 2, 132. https://doi.org/10.4172/2329-6798.1000132

[4] Kim J.-H., Emoto K., Lijima M. et al.: Polym. Adv. Technol., 1991, 10, 647. https://doi.org/10.1002/(SICI)1099-

1581(199911)10:11<647::AID-PAT918>3.0.CO;2-Y

[5] Kim B.-S., Hrkach J.-S., Langer R.: Biomaterials, 2000, 21, 259. https://doi.org/10.1016/S0142-9612(99)00174-X

[6] Lu S., Anseth K.: Macromolecules, 2000, 33, 2509. https://doi.org/10.1021/ma9915024

[7] Madaghiele M., Salvatore L., Demitri C., Sannino A.: Mater Lett., 2017, 5, 1. https://doi.org/10.1016/j.matlet.2018.02.048

[8] Ponnuvely D., Kim S., Lee J.: Micro Nano Syst. Lett., 2018, 218, 305. https://doi.org/10.1186/s40486-017-0056-8

「91 McAvoy K., Jones D., Thakur R.: Pharm. Res., 2018, 35, 36. https://doi.org/10.1007/s11095-017-2298-9

[10] Benoit D., Anseth K.: Acta Biomater., 2001, 1, 461.

https://doi.org/10.1016/j.actbio.2005.03.002

[11] Benoit D., Durney A., Anseth K.: Biomaterials, 2007, 28, 66. https://doi.org/10.1016/j.biomaterials.2006.08.033

[12] Lin-Gibson S., Bencherif S., Cooper J. et al.: Biomacromolecules,

2004, 5, 1280. https://doi.org/10.1021/bm0498777
[13] Hensen K., Mahaim C., HiSlderich W.: Appl. Catal. A-Gen., 1997, 149, 311. https://doi.org/10.1016/S0926-860X(96)00273-6 [14] Seghier S., Belbachir M.: Iran J. Sci. Technol. Trans. Sci., 2018, 3, 1. https://doi.org/10.1007/s40995-018-0629-2

[15] Derdar H., Belbachir M., Harrane A.: BCREC, 2018, in press. https://doi.org/10.9767/bcrec.0.0.2692.xxx-xxx

[16] Belbachir M., Bensaoula A.: Pat. US 066969 0101, 2001.

[17] Belbachir M., Bensaoula A.: Pat. US 7, 094, 823 B2, 2006.

[18] Hennaoui F., Belbachir M.: J. Macromol. Sci. A, 2015, 52, 992. https://doi.org/10.1080/10601325.2015.1095602

[19] Baghdadli M., Meghabar R., Belbachir M.: Asia J. Chem., 2016, 28, 1197. http://doi.org/10.14233/ajchem.2016.19620

[20] Draoua Z., Harrane A., Belbachir M.: J. Macromol. Sci. A., 2015, 52, 130. https://doi.org/10.1080/10601325.2015.980763 [21] Derdar H., Belbachir M., Hennaoui F. et al.: Polym. Sci. B, 2018, 60, 555. https://doi.org/10.1134/S1560090418050056

[22] Gorniak K., Szydlak T., Gawel A.: Appl. Clay Sci., 2017, 141, 180. https://doi.org/10.1016/j.clay.2017.02.032

[23] Simon G., Allen P., Wiliams D.: Polymer, 1991, 32, 2577. https://doi.org/10.1016/0032-3861(91)90337-I

[24] Yahiaoui A., Belbachir M.: J. Appl. Polym. Sci., 2006, 100, 1681. https://doi.org/10.1002/app.22946

Received: December 12, 2018 / Revised: January 26, 2019 / Accepted: May 28, 2019

\section{НОВИЙ ЕКОЛОГІЧНИЙ КАТАЛІЗАТОР ДЛЯ СИНТЕЗУ БІС-МАКРОМОНОМЕРІВ ПОЛТТИЛЕНГЛІКОЛЮ (ПЕГ)}

\begin{abstract}
Анотація. Розроблено новий метод синтезу димекрилату поліетиленгліколю (PEGDM) з різною молекулярною масою (1000, 3000, 6000 і 8000 г/моль) поліетиленгліколю (PEG). Maghnite- $H^{+}$застосований як еко-каталізатор для заміни токсичного триетиламіну. Maghnite- $H^{+}$являе собою протонобмінну монтмориллонітову глину, приготовану за допомогою звичайного обмінного процесу. Синтез проводили з використанням дихлорметану як розчинника в присутності метакрилового ангідриду. Досліджено вплив часу реакиії, температури, кількості каталізатора та кількості метакрилового ангідриду для визначення оптимальних умов реакції. Встановлено, щчо найкрашчий вихід (98\%) досягається за кімнатної температури протягом 5 год. Структура отриманих макромономерів (PEGDM) підтверджена Фур'є-спектроскопією, ${ }^{1}$ Н ЯМР $i{ }^{13}$ С ЯМР методами. За допомогою термогравіметричного аналізу визначено термічну стабільність отриманих макромономерів. Наявність ненасиченої кінщевої групи підтверджено УФ-спектроскопією.
\end{abstract}

Ключові слова: РEGDM, одноступеневий синтез, Maghnite- $H^{+}$, макромономери, метакриловий ангідрид. 